petent successor who would feel both a plea. sure and a pride in faithfully discharging the important offices which his sense of duty would impel him to fulfil? This is by no means an extraragantly conceived, or imaginary exemplification, either of contempt of obligations seriously imposed, or of human depravity, as exemplified in our medical locusts. I could, in support of my argument, name, if necessary, an individual who has practically illustrated by his conduct for the last twenty years the truth of the position I here lay down; and I could likewise mention three or four instances of salu. tary exchanges which have taken place in hospital appointments, although they were effected chiefly by private arrangement. Give me leave to add that, in my opinion, the man who obstinately perseveres in monopolizing an important medical situation, and will, in the dog-and-the-manger fashion, neither do the duty, nor resign, but takes advantage of his spurious interest and vitiated influence with a corrupt committee, is much more culpable than a person who would vacate even for a pecuniary consideration. As long as the present system is permitted to continue in operation, and human nature remains what it is, moralize as we may,nepotism, patronage, and money, will exert a preponderating influence in determining nedical appointments, both in Great Britain and Ireland, and the " infamous traffic and practice" will go uninterruptedly on, until restrained by the powerful arm of legislative cnactment. It appears to me that the adoption of the principle of the concours in reference to hospital appointments in these countries would be the most efficacious method of putting a stop to the "flagrant abuse" complained of; and that it is only by rendering the commission of "the crime" impracticable, that "the weapon" can be effectively wrested from "the aggressor." This is the opinion I expressed, arid the doctrine which I endeavoured to promulgate, when delivering my unimportant sentiments on the important subject of MEDICAL REFORM.

I have the honour to remain, with great respect, your obedient humble servant,

47, William-street, Dublin, Andrety Ellis.

Nov. 28 th, 1835.

\section{DELIRIUM WITH TREMOUR.}

To the Editor.-Sin,- Tour correspondent respecting Delirium Tremens, in your last number,-and who need not have apfened anonymously in the matter,--is certainly correct in supposing that I have inadvertently overlooked the reforence I have male to Dr. Elliotson's lecture. I find that his leeture was pobli:hed on the 12th of Jannary 3833 , and that my article on the subject $w a s$ in the printer's hands at the time; this and other iffertaces having been afterward atried in the proof. Upon referring to my article, I observe, that the names I have suggested amoug the synonymes are, "Idiopathic Delirium;-Delirium Tremefaciens;" and I have accordingly placed the word "author" after them. As to tlie pathological doctrine and division 1 have claimed, $I$ remain of the same opinion as betore. Upon looking into my fifend Dr. Eligotson's able lecture, I foumd that part of it which is devoted to delifium trcmens methodically arrangerl into "symptoms," "Causes," "Diagnosis," and " Tieatment;" but I could not find the distunctions in question under either of the beads "symptoms" and "Diagnosis," " were I expected to fond them; and it was not until I had arrived nearly at the conclusion of the "Treatment;" that I found the subject adverted to, and there only in an incidental inanner. I may take occasion to state, that the first case which directed my attention to the distinction in question occured in a dispensary patient in 1821 ; and that, abont ten years ago, i attended, wilhin a few months of each vther, three cazes of the disease. with Mr. Houlton, of Lisson Grove, a gentleman well known to Dr. Elliotion and myself for his extencive literary and scientifir acquitements, as well as for his expenience; and one of those cases presented the infammatory chardets $r s$, and occurred under the circumstances which I have detailed at length. I do not dispnte that the distinction was made about the same time by Dr. Elliotson and myself; but that $I$ have been indebied to his lecture I unequivocally deny. Whoever will first iead Dr. E.'s lecture, and immediately afterwards my articles on "Delirium," and "Delitium with tiemow", will find internal evidence of my originality. If I may judge from my feelings and habils, I should infer thist, in glancing-for 1 can do no more in many instances, even where 1 make references-over this lecture, I perceived noliing vbich particularly stink ine, otherwise 1 nou'd have taken further notice of it; and that the topic in question shonld have escaped me is not sur prising, when the head under which it was inticed, both bifefly and incidentally, is taken into account.

$$
\text { I am, Sir, your obedient servant, }
$$

Bulstrode-street, Nov. 30,1835

James Copland.

\section{CORRESPONDENTS.}

WE have received another communication from $\mathrm{Mr}$. RogERs, in reply to the letter of Mr. G. Bury, relative to the proceedings at the late inquest at Farnham. We think we shall best consult the ends of justice by excluding from our columns any further remarks on the subjects in dispute until we have obtained on official copy of the depositions taken at the inquest. It is not ne. cessary to say one word in justification of the conduct of Mr. Rogers. He has manfully stepped forward to protect the character of an innocent man; and in doing so, will obtain the approbation of every just intelligent member of society.

WE have not space for the letter signed $C$., but we give insertion, for the satisfaction of the writer and the information of his friends, to the following passage, which is strictly applicable to the case, from the excellent work of Jervis on the office and duty of Coroners. Nothing can be more evident than the fact that no inquest should have been held on the occasion in question :-

"The dying suddenly is not to be understood as relating to a fever, an apoplexy, or other visitation of God, and Coroners ought nct in such cases, to obtrude themselves 